\title{
ANALISIS KESALAHAN MAHASISWA DALAM MENYELESAIKAN HUKUM COLUMB
}

\author{
Jeffry Handhika ${ }^{1}$, Suparmi $^{2}$, Cari $^{3}$ \\ ${ }^{1}$ Prodi Pendidikan Fisika FPMIPA \\ IKIP PGRI MADIUN \\ jeffry.handhika@yahoo.com \\ ${ }^{2,3}$ Prodi Ilmu Fisika Pascasarjana \\ Universitas Sebelas Maret Surakarta \\ suparmiuns@gmail.com
}

\begin{abstract}
ABSTRAK
Hukum Coloumb merupakan bahan kajian yang diperoleh mahasiswa ketika menempuh matakuliah Fisika Dasar II. Dalam penelitian ini, ditemukan kesalahan dalam menyelesaikan soal penerapan hukum Coloumb. Kesalahan dalam menentukan arah gaya Coloumb dialami oleh semua mahasiswa Fisika. Ditemukan bahwa ketidakpahaman konsep gaya Coloumb mempengaruhi kesalahan mahasiswa dalam menyelesaikan masalah gaya Coloumb. Solusi penyelesaian bertahap penentuan arah vektor gaya dapat mengatasi masalah yang dialami mahasiswa.
\end{abstract}

Kata Kunci: Kesalahan Mahasiswa, Hukum Coloumb

\section{Pendahuluan}

Penelitian hukum Coloumb banyak dilakukan oleh peneliti fisika, Sallabi A. K, Khaliel J. A, Mohamed A. S (2014) meniliti distribusi menyimpang pada hukum Coloumb, Haller Jr J. L. (2014), Mengkaji kaitan hukum Coloumb dan hukum Newton Jonson J. O (2008) menjadikan hukum coloumb menjadi pengetahuan dasar Elektromagnetik. Hukum Coloumb merupakan bahan kajian yang diperoleh mahasiswa ketika menempuh matakuliah Fisika Dasar II. Asumsi awal peneliti, mahasiswa tidak menemui kendala dalam menyelesaikan permasalahan hukum Coloumb karena sudah pernah mendapatkannya di SMA. Peneliti memprofilkan prediksi persepsi mahasiswa berdasarkan pengalaman selama mengajar matakuliah ini. prediksi sebagai berikut.

1. Transformasi bentuk vektor gaya Coloumb

2. Mahasiswa mengalami kesalahan dalam menentukan tanda (+) dan tanda (-) pada muatan.

Dua prediksi yang dikemukakan diatas akan muncul saat menyelesaikan permasalahan dan proses belajar dan pembelajaran berlangsung. Prediksi nomor satu tidak muncul begitu saja, prediksi nomor satu akan mudah muncul ketika dosen memberikan apersepsi materi sebelumnya dan mengkaitannya dengan materi yang akan diajarkan. Bagi mahasiswa yang memiliki kemampuan analisis yang baik, pemberian apersepsi mungkin tidak diperlukan untuk memunculkan prediksi nomor satu.

Prediksi nomor dua dimunculkan dengan memberikan persamaan gaya Coloumb dalam bentuk vektor lengkap. Selama di SMA, mahasiswa hanya diperkenalkan pada bentuk persamaan gaya coloumb sederhana tanpa melibatkan bentuk vektor. Dengan memberikan permasalahan hukum coloumb dan memberikan representasi bentuk hukum coloumb dan penerapan hukum coloumb dalam permasalahan fisika akan diidentifikasi profil mahasiswa dalam menyelesaikan masalah hukum coloumb.

\section{Metode}

Penelitian ini merupakan penelitian pendahuluan yang dilaksanakan pada mata kuliah Fisika Dasar II pokok bahasan hukum Coloumb. Subyek yang dikaji sebagai sumber data adalah mahasiswa semester 2 genap 2013/2014 sebanyak 27 
orang. Pengumpulan data menggunakan teknik tes dengan soal essay pada kompetensi hukum coloumb, wawancara terstruktur berkaitan dengan pemahaman tentang hukum Coloumb. Analisis data menggunakan analisis deskriptif kualitatif (Sutopo:2006).

\section{Hasil Penelitian dan Pembahasan}

Hasil penelitian menunjukkan bahwa 1 orang mempertanyakan bentuk hubungan persamaan gaya pada gaya coloumb, pertanyaan ini sudah diprediksi sebelumnya. Kemunculan pertanyaan ini tentu saja wajar karena mahasiswa sebelumnya pernah mendapatkan matakuliah fisika dasar I. Bentuk persamaan gaya yang mereka kenal adalah $\vec{F}=m . \vec{a}$. jika dikaitkan bentuk ini dengan persamaan fungsi $r$, pemahaman mahasiswa terbatas pada

$$
\boldsymbol{F}=m \frac{d^{2} r}{d^{2}}
$$

Pada persamaan (1) persepsi mahasiswa menyatakan bahwa bentuk hubungan tersebut memberikan informasi bahwa $\mathbf{F}$ berbanding lurus dengan $\mathbf{r}$ kuadrat.

\section{$F=$}

$k \frac{q_{1} q_{2}}{r^{2}}$

sedangkan pada persamaan gaya Coloumb, $\mathrm{F}$ berbanding terbalik dengan $\mathrm{r}$ kuadrat. Mahasiswa mengalami kebingungan ketika kedua persamaan tersebut disandingkan. Alternatif solusi yang dapat digunakan untuk menjawab pertanyaan mahasiswa tersebut adalah dengan mempertegas fungsi dt kuadrat pada persamaan (1). Walaupun dilakukan analisis dimensi, $\mathrm{F}$ berbanding lurus dengan $r$ kuadrat pada persamaan (1), namun sebenarnya fungsi $\mathrm{dt}$ dan $\mathrm{d} \vec{r}$ (vektor) sangat mempengaruhi. Jika tidak ada perubahan $t$, maka gaya $F$ akan memiliki nilai yang sangat besar. Walaupun cara ini belum dapat meyakinkan mahasiswa pada saat pelaksanaanya, namun menjadi penting sekali untuk diinformasikan ke mahasiswa. Untuk meyakinkan mahasiswa tentang kesamaan bentuk fungsi tersebut, bentuk energi dapat menjadi pendekatan yang paling baik.

Jika persamaan (1) kita ubah bentuknya menjadi

$W=$

$\boldsymbol{F} . \Delta \boldsymbol{r}$

Persamaan (2) kita ubah bentuknya menjadi F. $r=$ $k \frac{q_{1} q_{2}}{r}$.

Persamaan (4) merupakan bentuk sederhana dari energi ( ruas kanan). Walaupun bentuk persamaan (4) sudah dapat meyakinkan mahasiswa tentang hubungan persamaan (1) dan (2) namun belum secara rinci menjelaskan bentuk vektor dari persamaan (2). Persamaan (3) dan (4) juga memberikan masalah baru. Pada persamaan (3) W berbanding lurus dengan $r$, dan pada persamaan (4) W berbanding terbalik degan r. jika diintepretasikan dalam bentuk grafik persamaan (3) dan (4) dapat dilihat pada gambar (1).

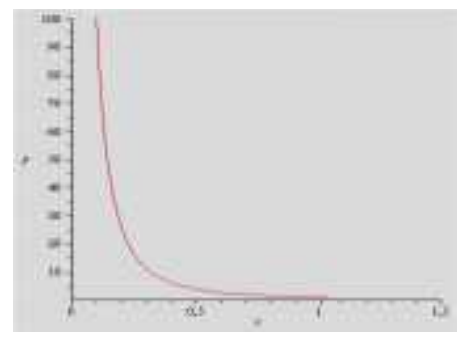

b

Gambar 1.a. Representasi Gambar Persamaan (1)

1.b. Representasi Gambar Persamaan (2) 
Gambar 1, a dan b menambah kebingungan terhadap hubungan kedua persamaan tersebut. Dalam penelitian Lee G. \& Yi J. (2013), bentuk repesentasi gambar (1) merupakan salah satu cara pemberian konflik kognitif.

Persamaan (5) merupakan bentuk lengkap dari persamaan (2), Jakson D. J. (1999).

$\boldsymbol{F}=q \boldsymbol{E}$

Persamaan (5) dapat diubah bentuknya menjadi

$$
\begin{aligned}
& \boldsymbol{r}= \\
& k q_{1} q_{2} \frac{\boldsymbol{x}_{1}-\boldsymbol{x}_{2}}{\left|\boldsymbol{x}_{1}-\boldsymbol{x}_{2}\right|^{3}} \\
& \text { Jakson D. J. } \\
& \text { (1999). }
\end{aligned}
$$

Pada persamaan (6) sudah tampak bentuk vektor dari gaya Coloumb. Pada tahap ini mahasiswa yang belum mengenal sama sekali. F adalah besaran vektor, vektor satuan $\mathbf{x}_{1}$ dan $\mathbf{x}_{2}$ juga merupakan bentuk vektor. Jika bentuk vektor persamaan (6) disederhanakan, maka akan kembali pada bentuk persamaan (2). Representasi gambar perlu disajikan untuk menjelaskan persamaan (6).

Hasil penelitian yang kedua menunjukkan bahwa mahasiswa mengalami kesulitan dalam menyelesaikan penentuan gaya Coloumb, terutama dalam penentuan tanda positif dan negatif gaya Coloumb.

Contoh soal tes yang kami gunakan adalah sebagai berikut:

Empat buah muatan sejajar sumbu horizontal seperti gambar 2. Besar masingmasing muatan $\mathrm{q}_{\mathrm{A}}=5 \mu, \mathrm{q}_{\mathrm{B}}=3 \mu, \mathrm{q}_{\mathrm{C}}=$ $2 \mu, \mathrm{q}_{\mathrm{D}}=4 \mu$. Tentukan resultan gaya ditinjau dari $\mathrm{q}_{\mathrm{B}}$. Sumber (T. Wayne).

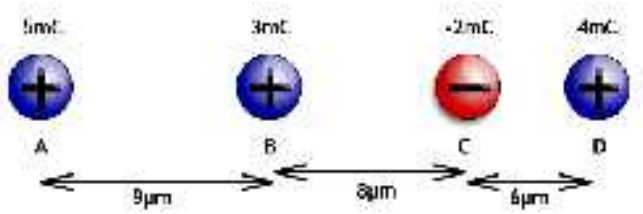

http://www.mrwaynesclass.com/coulomb/reading/index01.html. Gambar 2. Empat Muatan Sejajar

Ada empat kesalahan yang dapat diprofilkan dari soal nomor 2, kesalahan pertama disebabkan karena mahasiswa hanya memasukkan persamaan gaya coloumb dalam persamaan. Kesalahan kedua mahasiswa memasukkan tanda negatif pada muatan ke dalam arah, mahasiswa tidak menentukan arah dulu, melainkan langsung subtitusi. Kesalahan ketiga, pemahaman mahasiswa tentang indentifikasi "ditinjau dari" pada soal, sehingga terjadi kesalahan tanda positif dan negatif. Profil Kesalahan 1 dan 2 dapat dilihat pada tabel 1 .

Tabel 1. Profil Kesalahan yang dilakukan Mahasiswa.

\begin{tabular}{cccc}
\hline No. & $\begin{array}{c}\text { Kesalahan yang } \\
\text { dilakukan } \\
\text { Mahasiswa }\end{array}$ & $\begin{array}{c}\text { Mahasiswa } \\
\text { yang } \\
\text { Mengalami } \\
\text { Kesalahan }\end{array}$ & $\begin{array}{c}\text { Persentase } \\
\text { yang } \\
\text { mengalami } \\
\text { kesalahan }\end{array}$ \\
\hline $1 . \quad$ & $\begin{array}{l}\text { Transformasi } \\
\text { Bentuk Vektor } \\
\text { Gaya Coloumb }\end{array}$ & 27 & $100 \%$ \\
\hline $2 . \quad$ & $\begin{array}{l}\text { mengalami } \\
\text { kesalahan dalam } \\
\text { menentukan } \\
\text { tanda (+) dan } \\
\text { tanda (-) pada } \\
\text { muatan }\end{array}$ & 27 & $100 \%$ \\
\hline
\end{tabular}

Kesalahan no 1 dan 2 memiliki keterkaitan, berdasarkan hasil wawancara dengan mahasiswa, diperoleh informasi bahwa mereka hanya mengenal bentuk skalar gaya Coloumb, mengenai bentuk vektor tidak di bahas, pengalaman dan pemahaman awal yang mereka miliki hanya sampai pada tahap pengaplikasian persamaan gaya coloumb pada soal. Berdasarkan data yang diperoleh pada saat awal pembelajaran, diperoleh informasi awal bahwa mahasiswa tidak memahami gaya coloumb, ada satu orang mahasiswa yang menulis gaya coloumb dengan persamaan $\mathrm{Q}=$ i.t (Gambar 2). 


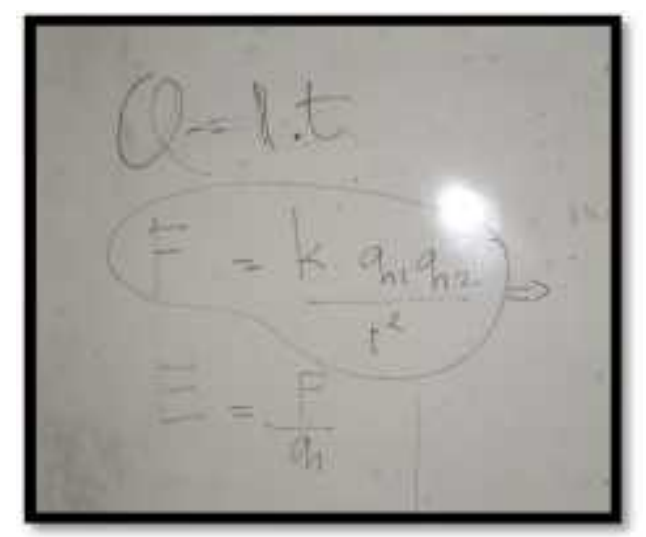

Gambar 3. Pekerjaan mahasiswa di papan tulis

Pada gambar 2, terlihat bahwa ada mahasiswa yang tidak mengingat persamaan gaya coloumb. Setelah dilakukan wawancara dengan mahasiswa yang bersangkutan, system drill dan hafalan persamaan menjadi metode yang digunakan sebelum duduk di bangku kuliah, dampaknya peluang untuk mengalami lupa

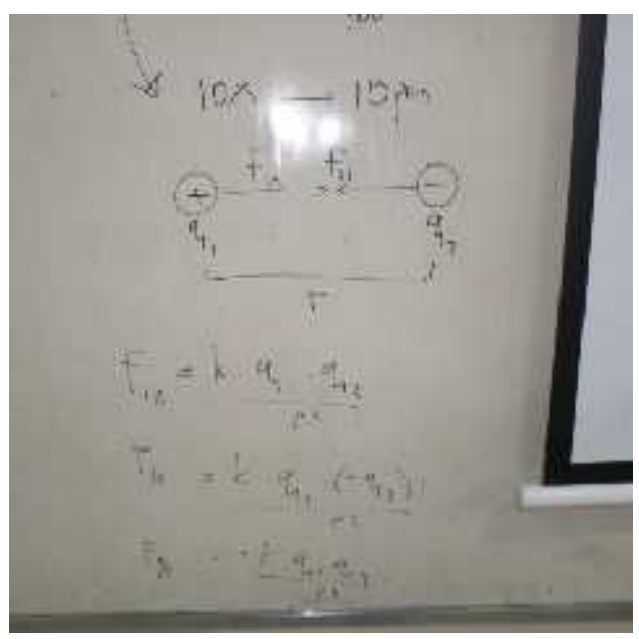

Gambar 4.a. Subtitusi tanda Negatif Pada Muatan

Hasil ini juga memperkuat kesalahan mahasiswa dalam mengerjakan soal nomor dua, dengan menganggap muatan merupakan besaran vektor dan mendukung profil pada kesalahan dua. Dari catatan yang dibuat oleh mahasiswa, penggunaan rumus segitiga yang ditampilkan pada gambar 4 mendukung bahwa mahasiswa selama ini hanya menghafal tanpa memahami persamaan dan konsep secara menyeluruh. Pritchard, A.(2009) lebih besar. Uji kemampuan awal dengan cara menuliskan di whiteboard juga memnunjukkan bahwa mahasiswa tidak memahami konsep hokum Coloumb. Mahasiswa memasukkan tanda negatif pada muatan dalam menyelesaikan persamaan (gambar 3).

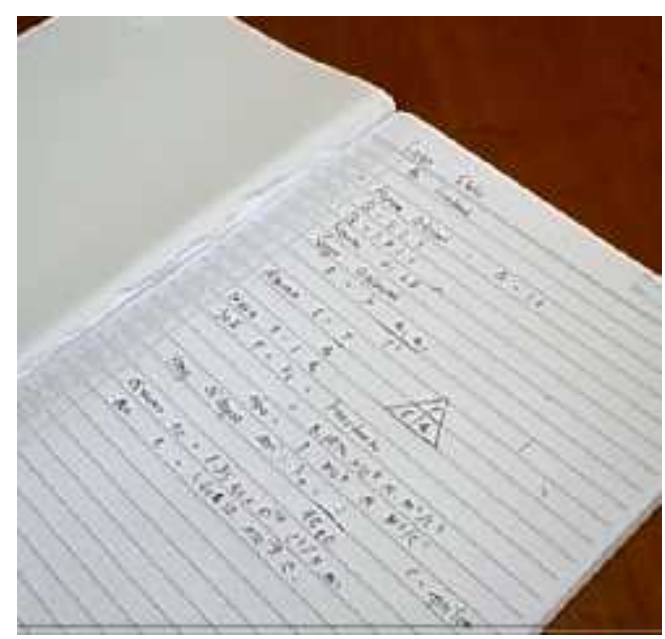

Gambar 4.b. Penggunaan Aturan Segitiga dalam Catatan mahasiswa

mengungkapkan "learning is the process of gaining more knowledge, or of learning how to do something - ride a bike, for example". Belajar merupakan proses mengembangkan pengetahuan, bukan menghafal informasi dan pengetahuan. 

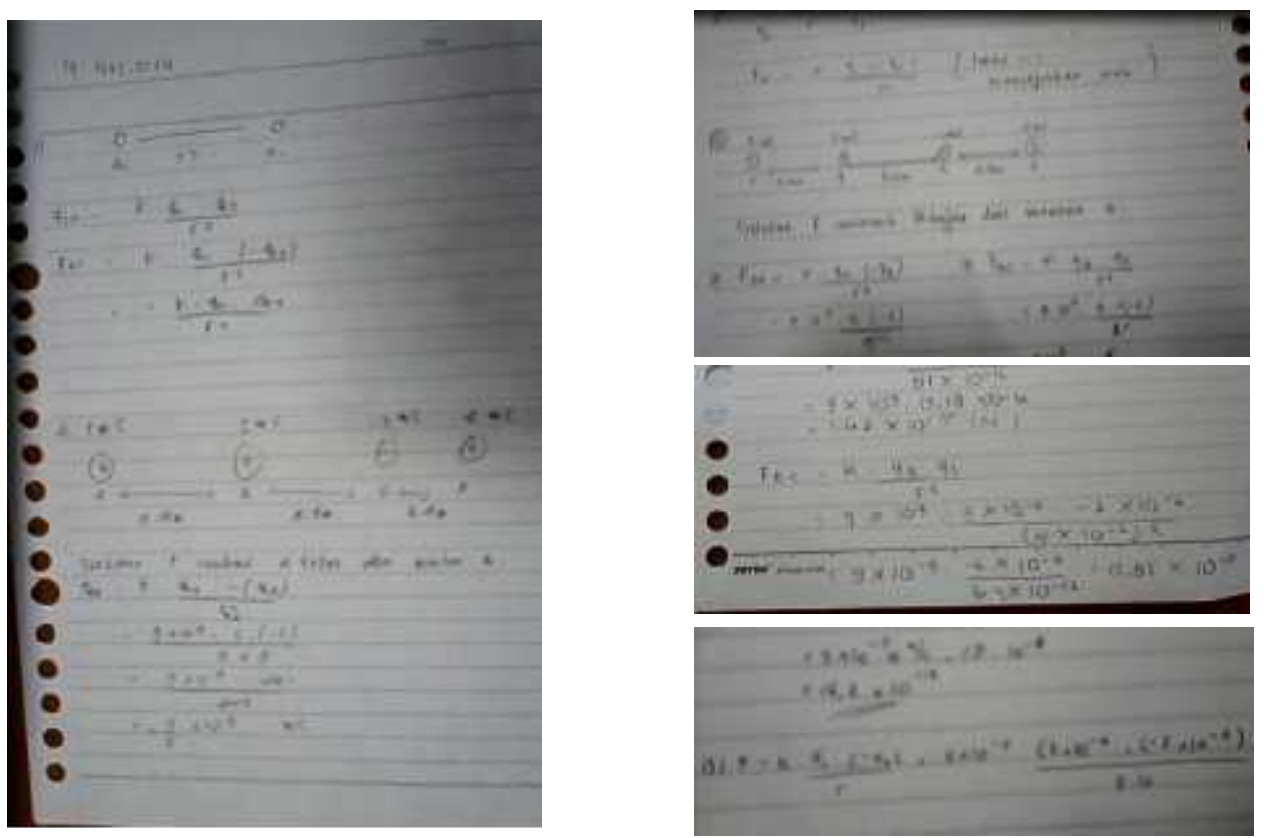

Gambar 5. Contoh Pekerjaan Mahasiswa

Pada gambar 5, terlihat bahwa dari pekerjaan mahasiswa dalam menyelesaikan gaya coloumb, hanya mensubtitusikan angka kedalam persamaan, kemudian menyelesaikan persamaan akhir dengan menjumlahkan seluruh gaya yang dihitung. Cara menghafal memang efektif dalam pembelajaran jangka pendek, namun dalam jangka panjang informasi yang diperoleh dari pembelajaran tersebut berpotensi mudah hilang atau rusak karena hanya tersimpan dalam memori jangka pendek. Informasi baru yang ditangkap panca indera masuk ke dalam memori jangka pendek yang memiliki kapasitas terbatas, di mana informasi dipertahankan sekitar 30 detik (Gagne, 1973). Informasi ini dapat hilang, kecuali informasi itu diulangi atau diproses lebih lanjut (bermakna) untuk diteruskan ke memori jangka panjang. Jika informasi dapat masuk ke memori jangka panjang, maka informasi terebut dapat tersimpan lama. Pembelajaran bermakna sangat penting agar informasi yang masuk dapat tersimpan dalam memori jangka panjang. Menurut Ausubel, Novak dan Hanesian dalam Suparno (2005: 53) "Belajar ada dua jenis yaitu belajar bermakna (meaningful learning) dan belajar menghafal (rote learning)". Belajar bermakna merupakan suatu proses belajar dimana informasi baru dihubungkan dengan struktur pengertian yang sudah ada pada diri seseorang yang sedang belajar. Dalam belajar bermakna mahasiswa mencoba menghubungkan fenomena baru ke dalam struktur pengetahuan yang ada, serta kesiapan dan niat dari mahasiswa untuk belajar dari kebermaknaan materi pelajaran secara potensial. Senanda dengan pernyataan tersebut Joan Josep Solaz-Portoles dalam lopez (2007) menytakan bahwa "To learn, the student has to unpack what he is taught and than repack in a way that suits his previous knowledge and his own learning style". Untuk belajar, mahasiswa harus membongkar apa yang telah dipelajarinya dan mengemas kembali berdasarkan pengetahuan yang telah didapat sebelumnya dengan caranya sendiri. Dengan cara seperti ini, pengetahuan yang didapat oleh mahasiswa akan lebih bermakna. Dengan kata lain mahasiswa harus memiliki kemampuan awal dan mampu mengkaitkan kemampuan awal tersebut dengan pengetahuan baru. Jika pengetahuan tersebut diperoleh dengan cara menghafal, maka mahasiswa akan mengalami kesulitan dalam mengkaitkan pengetahuan yang dimiliki dengan pengetahuan baru. Berdasarkan temuan pada Gambar 5, dosen memberikan tahapan dalam menyelesaikan permasalahan hukum Coloumb. Pertama (1) mahasiswa harus menentukan arahnya dulu, (2) besar gaya yang dihitung tanpa mengindahkan tanda negatif pada muatan, jadi besar gaya adalah positif. Dengan menggunakan cara ini, mahasiswa sudah mulai memahami bahwa q bukan besaran vektor, besaran vektor muncul ketika muatan q tersebut bergerak karena memiliki kecepatan, kecepatan 
tersebut merupakan besaran fektor yang mempengaruhi arah gaya. Dengan demikian, arah gaya ditentukan sesuai dengan arah pergerakan muatan yang ditinjau berdasarkan system koordinat kartesian. Cara ini cukup efektif dalam mengatasi permasalahan mahasiswa dalam menyelesaikan permasalahan gaya Coloumb. Pada tes berikutnya, dengan soal yang sama pada nomor dua, namun dengan tinjauannya yang berbeda, mahasiswa mengerjakan dengan baik. Semua mahasiswa sudah dapat mengerjakan soal dengan bernar dengan berbagai variasi model soal hukum Coloumb. Hasil setelah perlakuan akan dikaji pada publikasi selanjutnya.

\section{Simpulan}

Dari hasil pengkajian diatas, dapat disimpulkan sebagai berikut:

1. Mahasiswa mengalami kesulitan dalam menentukan arah gaya Coloumb, sehingga dalam menyelesaikan soal gaya Coloumb lebih dari dua muatan, mahasiswa mengerjakan salah.

2. Konsep awal mahasiswa tentang gaya Coloumb kurang, mahasiswa hanya menghafal persamaan tidak memahami persamaan

3. Solusi penyelesaian bertahap arah vektor gaya dapat mengatasi masalah penyelesaian gaya Coloumb dengan baik.

\section{Daftar Rujukan}

Haller J. R. J. L. (2014). A Stocastic Explination of Newton's Law and Coloumbs Law. Global Journal of Science Frontier Research: A Physics anf Space Science. Vo. 14 Issue 2. https://globaljournals.org/GJSFR_ Volume14/6-A-StocasticExplination-of-Newtons-Law.pdf
Jakson D. J. (1999). Calssical Electrodinamics. Samizdat Press

Jonson J. O. (2008). Turning Back to Coulomb's Law as a Basis for Electromagnetism. main contribution to the NPA conference.

http://worldnpa.org/abstracts/abstr acts_29.pdf

Lee G. \& Yi J. (2013). Where cognitive conflict arises from?: the structure of creating cognitive conflict. International Journal of Science and Mathematics Education. 11: 601Y623

Lopez V. S. Winter (2007). Cognitive Variables In Science Problem Solving. Journal of phisics taacher education online. Vol. 4. No. 2. : www.phy.ilstu.edu/jpteo. $\quad(18$ Agustus 2008, 02.15)

Pritchard, A.(2009) Ways of Learning. Second edition. Routledge 270 Madison Avenue, New York, NY 10016ISBN 0-203-88724-7

Sallabi A. K, Khaliel J. A, Mohamed A. S. (2014). Method of Images to Study the Charge Distribution in Cases of Potentials Deviating from Coulomb's Law. Journal of Electromagnetic Analysis and Applications, 2014, 6, 51-56

Sutopo. (2006). Penelitian Kualitatif dasar Teori dan Penerapannya. Universitas Sebelas maret.

Suparno. (2005). Guru Demokratis di Era eformasi. Jakarta : Grasindo.

http://www.mrwaynesclass.com/coulomb/re ading/index01.html. Diakses 02 Juli 2014 Pukul 04.30 WIB 